\title{
Effect of chronic thyroxine treatment on IGF-I, IGF-II and IGF-binding protein expression in mammary gland and liver during pregnancy and early lactation in rats
}

\author{
Roberto Rosato $^{1,2}$, Dicky Lindenbergh-Kortleve ${ }^{2}$, Johan van Neck ${ }^{2}$, Stenvert Drop ${ }^{2}$ and Graciela Jahn ${ }^{1}$ \\ ${ }^{1}$ Laboratorio de Reproducción y Lactancia, CRICYT-CONICET, 5500 Mendoza, Argentina and ${ }^{2}$ Laboratory of Pediatrics, Subdivision of Molecular \\ Endocrinology, Erasmus University, Rotterdam 3015GE, The Netherlands
}

(Correspondence should be addressed to R Rosato who is now at Medical College of Virginia, Virginia Commonwealth University, MCV Station Box 230 , Richmond, Virginia 23298, USA; Email: rrrosato@hsc.vcu.edu)

\begin{abstract}
Objective: Hyperthyroidism in rats produces organ hypertrophy and increases in circulating IGF-I and IGF-binding protein (IGFBP)-3. Chronic treatment with thyroxine $\left(\mathrm{T}_{4}\right)$ during pregnancy advances parturition, blocks lactation and changes several hormone receptors in mammary gland and liver. Since IGFs are implicated in mammary and liver growth and in differentiation, we studied the effects of hyperthyroidism, induced by daily injections of $\mathrm{T}_{4}(0.25 \mathrm{mg} / \mathrm{kg})$.

Design and Methods: Using quantitative RT-PCR and in situ hybridization, the gene expression of IGF-I, IGF-II and the IGFBPs was determined in mammary gland and liver of rats at estrus and days 7, 14 and 21 of pregnancy (G7, G14, G21), day 1 postpartum (L1) and 3 days after removing the litter (L4). Circulating levels of IGF-I, tri-iodothyronine $\left(\mathrm{T}_{3}\right)$, PRL and GH were measured.

Results: $\mathrm{T}_{4}$ treatment (HT) increased circulating $\mathrm{T}_{3}$ save on G21, did not change serum IGF-I, increased PRL on G21 and decreased GH on L1. PRL decreased on L1 because of the absence of lactation. Hepatic IGF-I mRNA was low during pregnancy and increased on L4. HT advanced this increase to L1. In controls, liver IGFBP-3 mRNA levels decreased from G14 to G21, whereas IGFBP-4 showed an inverse pattern. HT lowered IGFBP-3 mRNA and increased IGFBP-4. Increases in mammary concentrations of IGF-I, IGFBP-3 and IGFBP-4 mRNAs were seen on G21. HT delayed these peaks to L1. Mammary IGF-II and IGFBP-2 mRNA levels were high on G7 and G14, and fell afterwards, with HT having no effects. IGFBP-5 mRNA decreased during pregnancy and increased on L1. HT increased IGFBP-5 levels in early pregnancy and on L1. IGF-I mRNA localized to connective and epithelial mammary tissue, while IGFBP-2 and IGFBP-5 mRNA was only in epithelial cells.

Conclusion: These results imply a role for IGF-I, IGFBP-3 and IGFBP-4 in terminal mammary development, while IGF-II and IGFBP-2 may be implicated in early growth. IGFBP-5 has been implicated in mammary apoptosis, and the HT-induced increase may play a role in the premature mammary involution of the HT rats.
\end{abstract}

European Journal of Endocrinology 146 729-739

\section{Introduction}

Hyperthyroidism produces accelerations in metabolism and organ hypertrophy. It has also been shown to have deleterious effects on human and animal pregnancy (1). We have demonstrated that daily thyroxine $\left(\mathrm{T}_{4}\right)$ treatment $(1 \mathrm{mg} / \mathrm{kg})$ given for $35-40$ days to virgin rats produces marked organ hypertrophy and changes in protein and lipid content and in lipid metabolism (2). On the other hand, pregnancy attenuates some of the metabolic effects of this $\mathrm{T}_{4}$ regimen, both in dams and pre-term fetuses, when compared with virgin rats (2). We have demonstrated that a similar $(1 \mathrm{mg} / \mathrm{kg})$ or smaller $(0.25 \mathrm{mg} / \mathrm{kg})$ daily $\mathrm{T}_{4}$ treatment started 2 weeks before mating in rats, provoked an advancement in luteolysis, lactogenesis and parturition of roughly half a day (3), but the proportion of epithelial mammary tissue relative to adipocytes was markedly enhanced in the hyperthyroid rats (3), suggesting an increase in epithelial cell hypertrophy. In addition, $\mathrm{T}_{4}$ treatment induced changes in estradiol, progesterone, $\mathrm{GH}$ and prolactin (PRL) receptors in uterus, liver and mammary glands of late pregnant rats (4).

Insulin-like growth factors (IGFs) and their binding proteins (IGFBPs) are implicated in the growth and differentiation of most tissues, and mediate the actions of GH $(5,6)$. The main source of circulating IGFs and IGFBPs is the liver. However, IGFs and IGFBPs are 
also expressed in most organs and tissues. In addition to GH, IGF-I expression is regulated by insulin, thyroid hormones $(7-11)$ and the nutritional status $(12-15)$. Serum and hepatic IGFs and IGFBPs have been shown to vary during pregnancy and lactation (1619). There is a complex interaction between IGFs and IGFBPs. The latter have been shown to inhibit or to enhance IGF actions, depending on the tissue and experimental model and, conversely, their production seems to be regulated by the IGFs $(5,6)$. The expression of IGFs and their IGFBPs in various organs is differentially regulated by various hormonal factors, such as estrogens in the uterus (20), and they may be mediators in the organ hypertrophy produced by thyroid hormone excess. In mammary glands, IGFs, IGFBPs and their receptors are abundantly expressed, showing changes in concentration during pregnancy and lactation and hormonal regulation mainly by $\mathrm{GH}$ $(19,21-25)$. Circulating and mammary IGFs and IGFBPs play a role in mammary development during puberty as well as during pregnancy, acting as mitogens mediating mammogenesis $(26,27)$ and inhibiting involution $(28-30)$.

In order to determine whether IGFs and IGFBPs are involved in the effects of hyperthyroidism on mammary tissue development during pregnancy and postpartum, the effects of daily $\mathrm{T}_{4}$ treatment $(0.25 \mathrm{mg} / \mathrm{kg})$ on the expression of the IGF system was determined by quantitative RT-PCR and non-radioactive in situ hybridization. Similarly, mRNA expression was evaluated in the liver as an organ that suffers a marked hypertrophy during pregnancy and at the same time is the main source of circulating IGFs and IGFBPs.

\section{Materials and methods}

\section{Animals}

Adult female Wistar rats, 3-4 months old, bred in our laboratory and weighing 200-220 g were used. The rats were housed in an animal room with a 14-h light regimen (0600-2000 h) and controlled temperature $\left(22-24^{\circ} \mathrm{C}\right)$. Rat chow (Cargill, Cordoba, Argentina) and tap water were available ad libitum. Hyperthyroidism (HT) was induced by daily s.c. injection with $0.25 \mathrm{mg} / \mathrm{kg}$ body wieght l-thyroxine $\left(\mathrm{T}_{4}\right.$, a generous gift from Glaxo, Buenos Aires, Argentina) dissolved in 0.9\% $\mathrm{NaCl}$ alkalinized with $\mathrm{NaOH}$ to $\mathrm{pH}$ 9. Vaginal smears were taken daily. Rats were mated on the night of proestrus, and the presence of spermatozoa was checked in the vaginal smear the following morning. This day was designated day 0 of pregnancy. The rats were mated 8-10 days after the start of the treatments. Groups of $\mathrm{T}_{4^{-}}$or vehicle-treated rats were killed by decapitation at $1200 \mathrm{~h}$ on estrus after 18 or 35 days of treatment, on days 7, 14 and 21 of pregnancy $(\mathrm{G} 7, \mathrm{G} 15, \mathrm{G} 21)$ or on the first day postpartum (L1). Since the litters of hyperthyroid rats rarely survive after the first day postpartum, other groups of $\mathrm{T}_{4}$ - or vehicle-treated rats were isolated from the litters the day after delivery and killed on the fourth day postpartum (L4), to investigate the expression of IGFs and IGFBPs after premature weaning. Food intake was measured weekly.

The livers and inguinal mammary glands were immediately excised, frozen on liquid nitrogen $\left(-196{ }^{\circ} \mathrm{C}\right)$ and stored at $-80^{\circ} \mathrm{C}$ for RNA extraction. Trunk blood was collected and serum separated and stored at $-30{ }^{\circ} \mathrm{C}$ for hormone radioimmunoassays (RIA). For in situ hybridization, mammary glands were fixed in $4 \%$ paraformaldehyde and embedded in paraffin according to standard procedures. Sections $(4 \mu \mathrm{M})$ were mounted on 3-aminopropyl trioxysilanecoated slides.

\section{Hormone determinations}

PRL and GH were measured by double antibody RIA using materials generously provided by the National Hormone and Pituitary Program (NHPP), NIADDK, Bethesda, MD, USA). The hormones were radioiodinated using the chloramine T method and purified by passage through Sephadex G75 (3). The results are expressed in terms of rat PRL RP-3 or rat GH RP-2 standard preparations. Assay sensitivity was $0.5 \mu \mathrm{g} / \mathrm{l}$ serum and the inter- and intra-assay coefficients of variation were less than $10 \%$ for both hormones.

Tri-iodothyronine $\left(\mathrm{T}_{3}\right), \mathrm{T}_{4}$ and IGF-I in sera were measured by RIA using commercial kits for total hormones (DSL Coat-a-count total $\mathrm{T}_{3}$, coated tube RIA and total rat IGF-I RIA, DSL-2900, both from Diagnostic Products Corporation, Los Angeles, CA, USA).

\section{RNA extraction}

Total RNA was prepared according to the acidguanidine thiocyanate-phenol-chloroform method (31) as modified by Puissant \& Houdebine (32) from frozen samples conserved at $-80^{\circ} \mathrm{C}$. The amount of RNA recovered was measured by UV spectrophotometry and its quality and quantity verified by $1 \%$ agarose gel electrophoresis.

\section{Quantitative RT-PCR}

The non-competitive quantitative RT-PCR was performed as previously described (33) following the method originally reported by Pane et al. (34). An absolute amount of mRNA molecules is calculated by interpolating the generated amount of PCR products from sample RNA into a titration curve obtained by amplifying a known number of synthetic RNA molecules containing the same sequence as the RNA to be quantitated.

The synthetic mRNA used as standard was obtained as previously reported (33). Briefly, cDNA fragments of 
the desired sequences were amplified by performing PCR on the available cDNAs of the mouse IGF system (35). The fragments obtained were ligated into the pGEM-T vector (Promega, Madison, WI, USA), and a second PCR using $1 \mu \mathrm{l}$ of ligation mixture (1:1 diluted) as DNA template was performed. The T7 promoter sequence contained in the vector was used as $5^{\prime}$ primer, with gene specific 3'-primers (Table 1). The resulting PCR fragment contained the same sequence as that to be quantitated plus the $\mathrm{T} 7$ promoter sequence. This T7 fragment was purified and used for in vitro RNA transcription (Ribomax kit; Promega, Leiden, The Netherlands). The cRNA produced was purified and the number of molecules was estimated by using the molecular weight of the cRNA molecule, Avogadro's number and the spectrophotometric absorbance at $260 \mathrm{~nm}$.

RT-PCR was performed on both prepared standard RNA and extracted sample RNA. One microgram of total RNA was reverse transcribed with 200 units M-MLV reverse transcriptase (Gibco BRL, Breda, The Netherlands) primed with specific 3'-primers for IGF-I, IGF-II, IGFBP-1, -2, -3, -4 and -5 (Table 1) in a final volume of $20 \mu$ l. The PCR reaction was carried out in a final volume of $30 \mu \mathrm{l}$ with the equivalent of $30 \mathrm{ng}$ total RNA ( $3 \mu$ l of a 1:5 dilution of the RT reaction) in PCR buffer $\left(50 \mathrm{mM} \mathrm{KCl}, 1.5 \mathrm{mM} \mathrm{MgCl}_{2}\right.$ and $20 \mathrm{mM}$ Tris-HCl, pH 8.3) plus $200 \mu \mathrm{M}$ deoxy-NTPs, $\left[\alpha-\mathrm{P}^{32}\right] \mathrm{dATP}, 25 \mathrm{pmol}$ forward and reverse primers and $1 \mathrm{U}$ Hi-Taq DNA polymerase (Bioprobe Systems, Montreuil-sous-Bois, France). PCR reactions were performed separately using an initial denaturation at $94^{\circ} \mathrm{C}$ for $3 \mathrm{~min}$, followed by 25 cycles that included: $30 \mathrm{~s}$ at $94^{\circ} \mathrm{C}, 20 \mathrm{~s}$ annealing at $53^{\circ} \mathrm{C}$ (except for IGFBP- $2,45^{\circ} \mathrm{C}$ ) and $30 \mathrm{~s}$ at $72^{\circ} \mathrm{C}$. Products were analysed on a $2.5 \%$ agarose gel and bands corresponding to each specific PCR product were excised and the amount of incorporated radioactivity was determined by $\beta$-scintillation counting. Oligonucleotide primers designed for the amplification were purchased from Pharmacia Biotech (Roosendaal, The Netherlands).

\section{Probe preparation}

The IGFBP-2 to -5 cRNA probes were transcribed from templates described by Schuller et al. (36). As template for the IGFBP-1 cRNA probe, the mouse cDNA fragment Sph1-Sac1 was cloned into pTZ18R or pTZ19R (Pharmacia Biotech) for the antisense or sense probes respectively. cDNAs encoding mouse IGF-I and -II were kindly provided by Dr G I Bell (Howard Hughes Medical Institute, Chicago, IL, USA). Fragments were subcloned into pTZ18 and pTZ19 (EcoR1 for IGF-I and BamH1/Sac1 for IGF-II). Digoxigenin-11-UTP labeled RNA probes were prepared according to the manufacturer's description (Boehringer Mannheim GmbH, Biochemica, Mannheim, Germany) using T7 or SP6 RNA polymerase.

\section{In situ hybridization}

For proper comparison, sections of both control and $\mathrm{T}_{4}$-treated (HT) mammary glands of the sequential observation points were mounted on one slide. Sections were dewaxed, hydrated and incubated in the following solutions: $0.2 \mathrm{M} \mathrm{HCl}, 0.3 \%$ Triton-X 100 in phosphatebuffered saline (PBS), $5 \mu \mathrm{g} / \mathrm{ml}$ proteinase $\mathrm{K}\left(37^{\circ} \mathrm{C}\right), 4 \%$ formalin in PBS and finally acetylated with acetic anhydride diluted in $0.1 \mathrm{M}$ triethanolamine $(750 \mu \mathrm{l} / 200 \mathrm{ml})$. Until hybridization, sections were stored in a solution of $50 \%$ formamide in $2 \times \mathrm{SSC}$ at $37^{\circ} \mathrm{C}$. For hybridization, probes were diluted in hybridization solution $(50 \%$ deionized formamide, $10 \%$ dextran sulfate, $2 \times$ SSC, $1 \times$ Denhardt's solution, $1 \mu \mathrm{g} / \mathrm{ml}$ tRNA, $250 \mu \mathrm{g} / \mathrm{ml}$ herring sperm DNA) to a concentration of $100 \mathrm{ng} / \mathrm{ml}$, incubated at $68^{\circ} \mathrm{C}$ for $15 \mathrm{~min}$ and layered onto the sections. Sections were hybridized overnight at $55^{\circ} \mathrm{C}$ in a humid chamber. Post-hybridization washes were performed at $45^{\circ} \mathrm{C}$ using the following steps: $50 \%$ formamide in $2 \times \mathrm{SSC}$, $50 \%$ formamide in $1 \times$ SSC and $0.1 \times$ SSC. A 15 -min incubation with RNase T1 $(2 \mathrm{U} / \mathrm{ml}$ in $1 \mathrm{mM}$ EDTA in $2 \times \mathrm{SSC})$ at $37^{\circ} \mathrm{C}$ was followed by washes of $0.1 \times$

Table 1 Sequences of PCR primers and predicted PCR products.

\begin{tabular}{|c|c|c|}
\hline Amplified mRNA & Sense and antisense primers & Products $(b p)$ \\
\hline IGF-I & $\begin{array}{l}\text { 5'-AAAATCAGCAGTCTTCCAAC-3' } \\
\text { 5'-AGATCACAGCTCCGGAAGCA-3' }\end{array}$ & 299 \\
\hline IGF-II & $\begin{array}{l}5^{\prime} \text {-GCCCCGGAGAGACTCTGTGCG-3' } \\
5^{\prime} \text {-GCCCACGGGGTATCTGGGGAA-3' }\end{array}$ & 253 \\
\hline IGFBP-1 & $\begin{array}{l}5^{\prime} \text {-TCAAAAAATGGAAGGAGCCCTGCC-3' } \\
5^{\prime} \text {-GAGTATAAATATACTATATACTTAAATATT-3' }\end{array}$ & 337 \\
\hline IGFBP-2 & $\begin{array}{l}\text { 5'-TGGAGGAGCCCAAGAAGCT-3' } \\
5^{\prime} \text {-GGTTCACACACCAGCAACTC-3' }\end{array}$ & 228 \\
\hline IGFBP-3 & $\begin{array}{l}\text { 5'-GCCGCGGGCTCTGCGTCAACGC-3' } \\
\text { 5'-CTGGGACTCAGCACATTGAGGAAC-3' }\end{array}$ & 415 \\
\hline IGFBP-4 & $\begin{array}{l}5^{\prime} \text {-CCATCCAGGAAAGCCTGCAG-3' } \\
5^{\prime} \text {-TGGAAGTTGCCGTTGCGGTCACAG-3' }\end{array}$ & 298 \\
\hline IGFBP-5 & $\begin{array}{l}\text { 5'-TTGCCTCAACGAAAAGAGC-3' } \\
\text { 5'-AGAATCCTTTGCGGTCACA-3' }\end{array}$ & 377 \\
\hline
\end{tabular}


SSC at $45^{\circ} \mathrm{C}$ and $2 \times \mathrm{SSC}$ at room temperature. The digoxigenin-labeled hybrids were detected by antibody incubation performed according to the manufacturer's description (Boehringer Mannheim $\mathrm{GmbH}$ ) with the following modifications. A 1:2000 dilution of antidigoxigenin (Fab) conjugated to alkaline phosphatase was used for a 2.5-h incubation at room temperature. Afterwards, an extra washing step of $0.025 \%$ Tween in Tris-buffered saline $(\mathrm{pH}$ 7.5) was introduced. For staining, sections were layered with detection buffer (0.1 M Tris-HCl, 0.1 M NaCl, 0.05 $\mathrm{M} \mathrm{MgCl}_{2}, \mathrm{pH} 9.5$ ) containing $0.33 \mathrm{mg} / \mathrm{ml}$ 4-nitroblue tetrazolium chloride, $\quad 0.16 \mathrm{mg} / \mathrm{ml} \quad$ 5-bromo-4-chloro-3-indolyl-phosphate, $7.5 \%$ polyvinylalcohol (molecular weight 31 000-50 000; Aldrich Chemical Co. Milwaukee, WI, USA) and $1 \mathrm{mM}$ levamisol (Sigma Chemical Co., St Louis, MO, USA). The color reaction was performed in the dark and was stopped when the desired intensity of the resulting blue precipitate was reached. Sections were washed in $10 \mathrm{mM}$ Tris- $\mathrm{HCl}, 1 \mathrm{mM}$ EDTA, $\mathrm{pH}$ 8.0 , counterstained with periodic acid solution (PAS) and nuclear red solution, dehydrated with ethanol gradients and mounted with an ethanol-based mounting medium (Euparal; Chroma-Gesellschaft, Stuttgart, Germany). Control sections for morphological analysis were stained with hematoxylin and eosin.

\section{Statistics}

Statistical analysis was performed using Student's $t$-test or analysis of variance followed by the least significant difference between means $(\tau)$ test when more than two means were compared (37). Differences between means were considered significant at the $P<0.05$ level.

\section{Results}

\section{Circulating PRL, GH, T 3 and IGF-I concentrations during pregnancy and early postpartum in control and HT rats}

Administration of $\mathrm{T}_{4}$ doubled the serum concentrations of $\mathrm{T}_{3}$ in virgin rats and on $\mathrm{G} 7, \mathrm{~L} 1$ and $\mathrm{L} 4$. In contrast, the increase was only approximately $50 \%$ on G14 and there were no differences between groups on G21 (Fig. 1). Circulating IGF-I was high in virgin rats and on G7, and fell progressively during pregnancy to very low values at G21. After parturition, serum IGF-I concentrations rebounded to values not different from virgin rats. There were no differences between control or HT rats (Fig. 1). Food intake did not vary during the first 18 days of treatment with $\mathrm{T}_{4}$ in the virgin rats, but had increased significantly by approximately $7 \%$ (from $15.7 \mathrm{~g} /$ rat per day to $16.9 \mathrm{~g} / \mathrm{rat}$ per day, $P<0.05)$ by the last 10 days of treatment, days $25-$ 35. During pregnancy, food intake increased roughly to double the values of the virgin rats, and the $\mathrm{T}_{4}$-treated rats consumed $16 \%$ more food than the virgin rats
$(P<0.01)$. In the virgin rats, body weight increased significantly in both groups of rats (controls, 227士 $4 \mathrm{~g}$; HT at 18 days, 273 \pm 9 ; HT at 35 days, $261 \pm 6 \mathrm{~g}$ ), while after delivery there were no significant differences in body weight between control (294 $\pm 5 \mathrm{~g}$ ) and HT (280 \pm 8$)$ mothers. In virgin rats, liver weights increased significantly from $7.3 \pm 0.3 \mathrm{~g}$ in controls to $9.3 \pm 0.3 \mathrm{~g}$ after 18 days of treatment and to $9.8 \pm 0.3$ at 35 days of $\mathrm{T}_{4}$ treatment $(P<0.01)$. By the first day postpartum, liver weights had increased in both groups, and the significant difference between HT $(12.5 \pm 0.6 \mathrm{~g})$ and control $(12.5 \pm 0.6 \mathrm{~g})$ rats had disappeared. The weight of the inguinal-abdominal mammary glands was also similar on the first day postpartum in both groups (controls, $8.8 \pm 0.8 \mathrm{~g}$; HT, $8.33 \pm 0.8 \mathrm{~g})$.

In the control rats, serum PRL concentrations, measured at $1200 \mathrm{~h}$ on estrus or the different days of

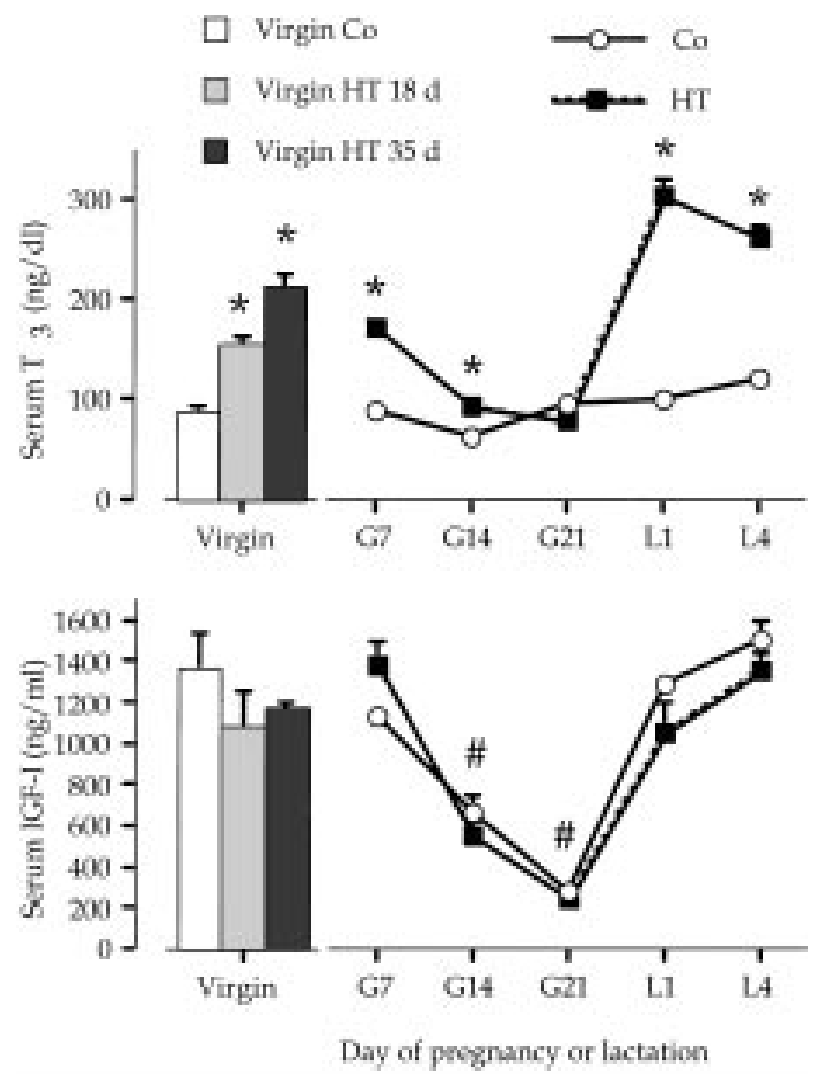

Figure 1 Serum concentrations of $T_{3}$ and IGF-I in virgin, pregnant and postpartum rats injected daily with $0.25 \mathrm{mg} / \mathrm{kg} \mathrm{T} \mathrm{T}_{4}(\mathrm{HT})$ or saline (controls; Co). Virgin HT rats were subjected to treatment for 18 days (HT $18 \mathrm{~d}$ ) or 35 days (HT $35 \mathrm{~d}$ ), to give approximately the same lengths of treatment for early pregnancy or late pregnancy and postpartum. Rats were killed at $1200 \mathrm{~h}$ on days 7 (G7), 14 (G14) and 21 (G21) of pregnancy or day 1 (L1) or 4 (L4) postpartum. $L 4$ rats had been separated from their litters on $L 1$. Serum hormones were measured by RIA. Results are expressed as means \pm S.E.M. of groups of four rats, with the exception of $L 1$ and $\mathrm{L} 4$, where there were groups of six to eight rats. ${ }^{*} P<0.05$ compared with respective control groups. ${ }^{\#} P<0.05$ compared with respective G7 group. 

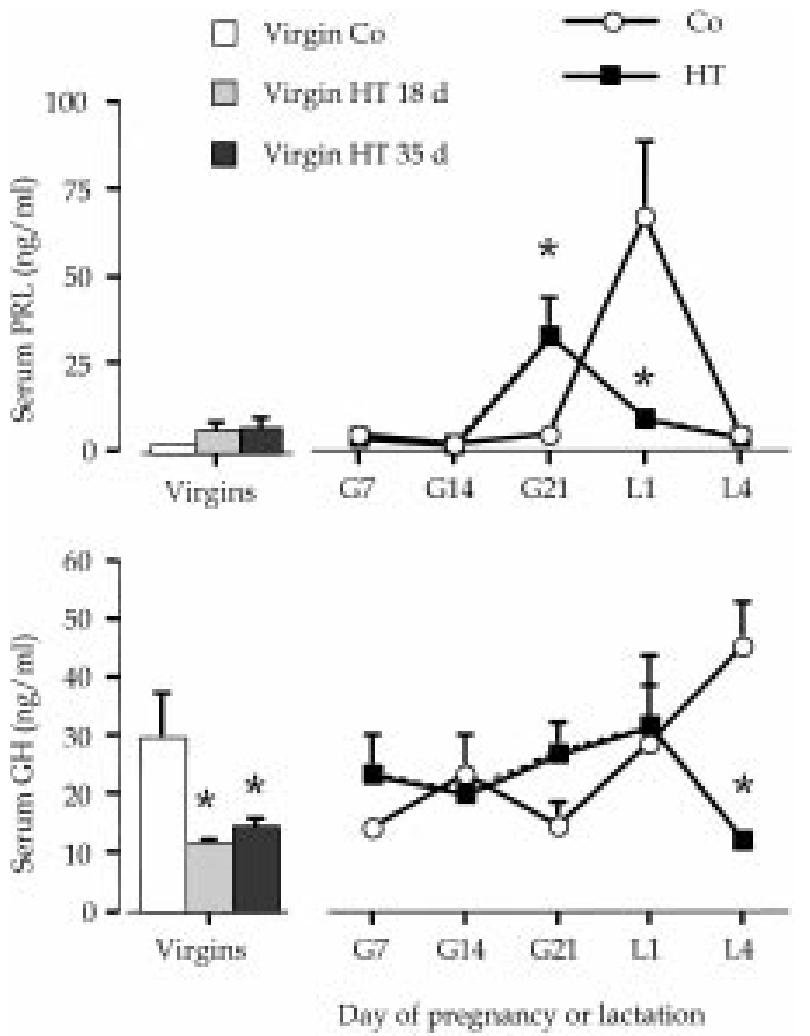

Figure 2 Serum concentrations of PRL and $\mathrm{GH}$ in virgin, pregnant and postpartum rats injected daily with $0.25 \mathrm{mg} / \mathrm{kg} \mathrm{T} \mathrm{T}_{4}(\mathrm{HT})$ or saline (controls; Co). Virgin HT rats were subjected to treatment for 18 days ( $\mathrm{HT} 18 \mathrm{~d}$ ) or 35 days (HT $35 \mathrm{~d}$ ), to give approximately the same lengths of treatment for early pregnancy or late pregnancy and postpartum. Rats were killed at $1200 \mathrm{~h}$ on days 7 (G7), 14 (G14) and 21 (G21) of pregnancy or day 1 (L1) or 4 (L4) postpartum. $L 4$ rats had been separated from their litters on $L 1$. Serum hormones were measured by RIA. Results are expressed as means \pm S.E.M. of groups of four rats, with the exception of L1 and $\mathrm{L} 4$, where there were groups of six to eight rats. ${ }^{*} P<0.05$ compared with respective control groups.

pregnancy or lactation, were high only in L1, as a consequence of the suckling stimulus, and had returned to basal levels on L4, 3 days after removal of the litters. In the HT rats, in contrast, serum PRL levels were elevated at midday on G21, as previously described (2), but were low on L1 (Fig. 2). Serum GH levels were significantly lower in HT rats at estrus and on L4, with no differences at the other time-points (Fig. 2).

\section{mRNA concentrations of IGF-I and IGF-II in mammary gland during pregnancy and early postpartum in control and $H T$ rats}

Since epithelial mammary tissue is very sparse in virgin mammary glands, which are composed mostly of connective and adipose tissue, we did not measure IGFs or IGFBPs in virgin tissues.

During pregnancy in control rats, mammary IGF-I mRNA levels decreased between G7 and G14, increased sharply at G21 and returned to values not different from G7 at postpartum. In contrast, in HT rats, the decrease was prolonged to G21, when the values were significantly lower than in control rats, and the sharp increase was shifted to L1, with values significantly higher than controls. At L4, mammary IGF-I mRNA concentration declined again, to values that were similar to those of G7, but lower than controls (Fig. 3).

IGF-II mRNA concentration in the mammary gland was very high during G7 and G14, and declined thereafter, reaching very low values on L4. In contrast to IGF-I mRNA levels, there were no differences between controls and HT rats (Fig. 3).

\section{mRNA concentrations of IGFBP-2 to -5 in mammary gland during pregnancy and early postpartum in control and $\mathrm{HT}$ rats}

No expression of IGFBP-1 mRNA was detected in the mammary glands. In control and HT rats, the levels


Day of pregnancy or lactation

Figure 3 IGF-I and IGF-II mRNA concentrations in mammary tissue from pregnant and postpartum rats injected daily with $0.25 \mathrm{mg} / \mathrm{kg} \mathrm{T} \mathrm{T}_{4}(\mathrm{HT})$ or saline (controls; Co) measured by quantitative RT-PCR. Rats were killed at $1200 \mathrm{~h}$ on days 7 (G7), 14 (G14) and 21 (G21) of pregnancy or day 1 (L1) or 4 (L4) postpartum. L4 rats had been separated from their litters on L1. Total RNAs were prepared from the tissues and $1 \mu \mathrm{g}$ subjected to RT-PCR. See Materials and methods section for details. Results are expressed as means \pm S.E.M. of groups of four rats. ${ }^{*} P<0.05$ compared with respective control groups, ${ }^{\#} P<0.05$ compared with respective G7 group. 
of IGFBP-2 were highest on G7, decreased to half on G14 and remained at the same values thereafter (Fig. 4). In control rats, IGFBP-3 showed variations comparable with IGF-I, with low values on G7 and G14, an increase on G21 and a return to G7 values on L1 and L4. In HT rats, the increase in IGFBP-3 mRNA levels was delayed to L1 (Fig. 4). Control animals demonstrated low IGFBP-4 mRNA levels on G7 and G14, and increased mRNA levels on G21 with maximal values on L1, and a return to values similar to G7 on L4. In HT rats, the increase in IGFBP-4 mRNA was delayed to L1 with a decrease on L4 to values that were significantly greater than the controls (Fig. 4).

In control rats, IGFBP-5 mRNA levels decreased from G7 to G21m and increased on postpartum, reaching the highest values on L4. HT rats had significantly higher values than controls on G7, showed a similar decrease during pregnancy, increased sharply on L1 to values higher than controls and remained high on L4 (Fig. 4).

\section{mRNA concentrations of IGF-I and IGFBP-2 to -5 in liver during pregnancy and early postpartum in control and $H T$ rats}

In the liver, we detected only mRNA for IGF-I and IGFBP-3 and -4 , and the results are shown in Fig. 5. No differences were observed between the 18- or 35day $\mathrm{T}_{4}$ treatment in the virgin HT rats.

IGF-I mRNA levels were similar in virgin rats and during pregnancy in control rats, with a significative increase on L4. IGF-I mRNA levels in HT rats were not different from controls in virgin rats and during pregnancy; however, they increased earlier, on L1. The values remained elevated on L4, at levels not significantly different from the controls (Fig. 5).

IGFBP-3 mRNA concentration was high in control rats, in virgin rats and on G7 and G14, with a marked decrease on $\mathrm{G} 21$ and $\mathrm{L} 1$ and a return to values not different from the virgin rats on L4. Virgin HT rats had values similar to controls, but showed a gradual decrease during pregnancy, which became
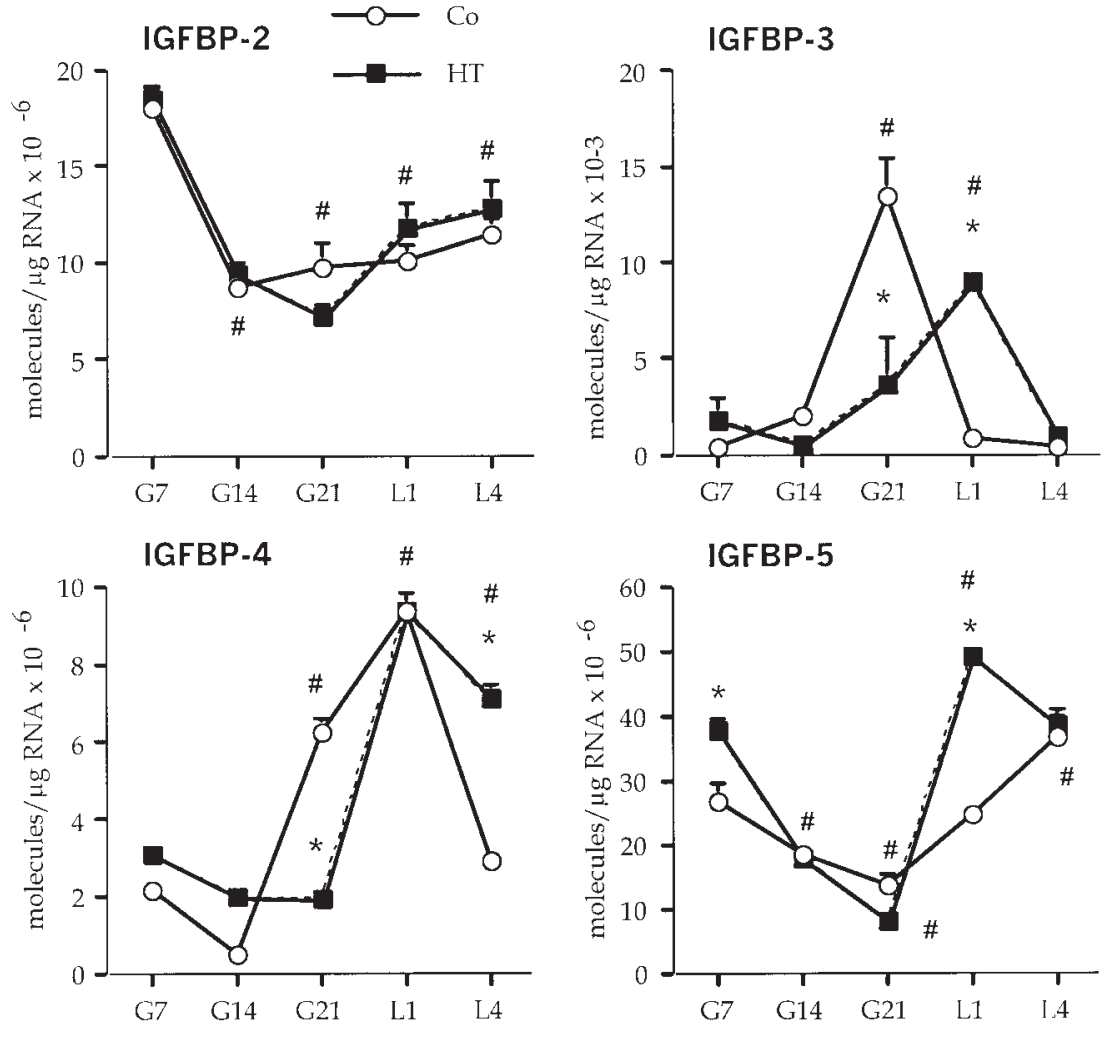

Day of pregnancy or lactation

Figure 4 IGFBP-2, $-3,-4$ and -5 mRNA concentrations in mammary tissue from pregnant and postpartum rats injected daily with $0.25 \mathrm{mg} / \mathrm{kg} \mathrm{T}_{4}(\mathrm{HT})$ or saline (controls; Co) measured by quantitative RT-PCR. Rats were killed at $1200 \mathrm{~h}$ on days 7 (G7), 14 (G14) and 21 (G21) of pregnancy or day 1 (L1) or 4 (L4) postpartum. L4 rats had been separated from their litters on L1. Total RNAs were prepared from the tissues and $1 \mu \mathrm{g}$ subjected RT-PCR. See Materials and methods section for details. Results are expressed as means \pm S.E.M. of groups of four rats. ${ }^{\star} P<0.05$ compared with respective control groups, ${ }^{\#} P<0.05$ compared with respective G7 group.

www.eje.org 

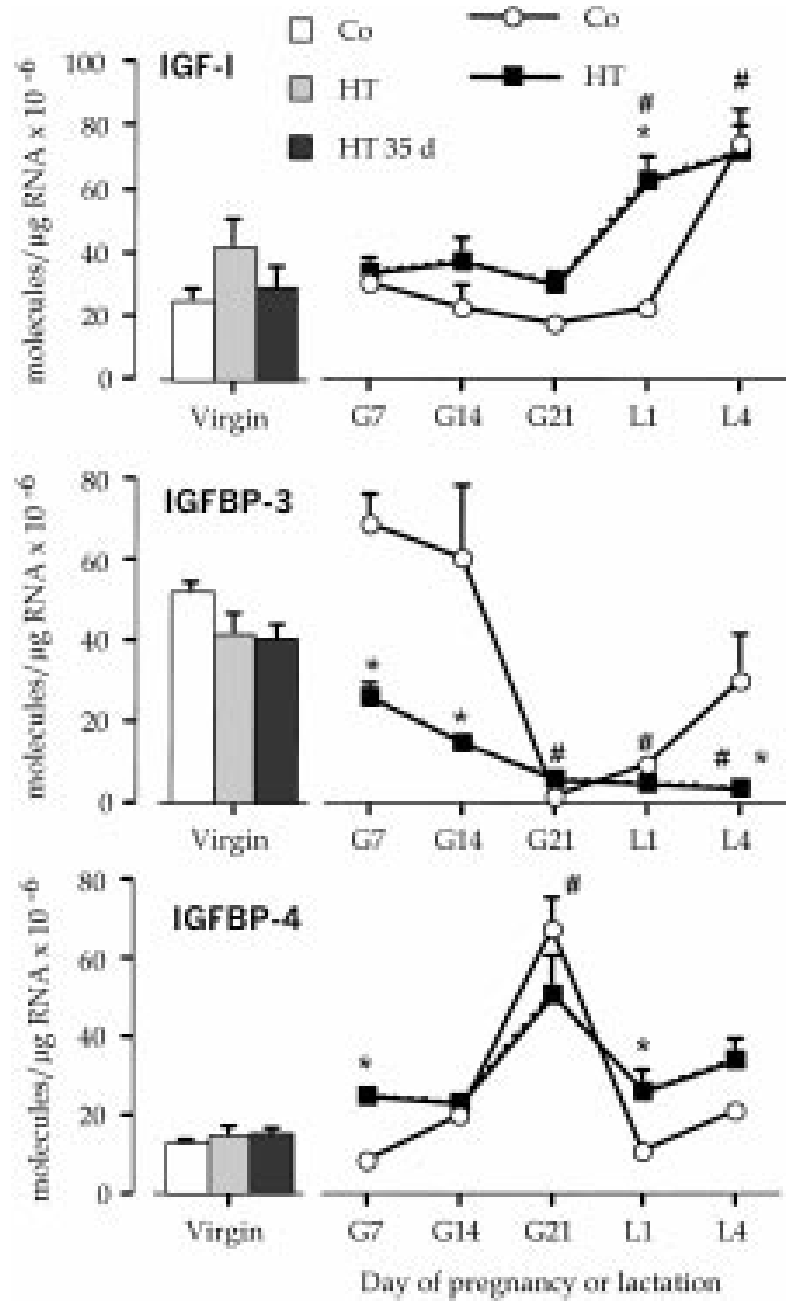

Figure 5 IGF-I and IGFBP-3 and IGFBP-4 concentration in liver in virgin, pregnant and postpartum rats injected daily with $0.25 \mathrm{mg} / \mathrm{kg} \mathrm{T}_{4}(\mathrm{HT})$ or saline (controls; Co) measured by quantitative RT-PCR. Virgin HT rats were subjected to treatment for 18 days (HT $18 \mathrm{~d}$ ) or 35 days (HT $35 \mathrm{~d}$ ), to give approximately the same lengths of treatment for early pregnancy or late pregnancy and postpartum. Rats were killed at $1200 \mathrm{~h}$ on days 7 (G7), 14 (G14) and 21 (G21) of pregnancy or day 1 (L1) or 4 (L4) postpartum. $L 4$ rats had been separated from their litters on $L 1$. Total RNAs were prepared from the tissues and $1 \mu \mathrm{g}$ subjected to RT-PCR. See Materials and methods section for details. Results are expressed as means \pm S.E.M. of groups of four rats. ${ }^{*} P<0.05$ compared with respective control groups, ${ }^{\#} P<0.05$ compared with respective virgin group.

statistically significant on G21 and thereafter, and with values significantly lower than controls on G7, G14 and L4 (Fig. 5).

Liver IGFBP-4 mRNA concentration in controls showed an inverse pattern to that of IGFBP-3. Values in virgin rats and early pregnancy were low. On G21 they markedly increased and returned to virgin values on postpartum. HT rats showed a similar pattern, but values were higher than controls on G7 and L1 (Fig. 5).

\section{Localization of mRNA by in situ hybridization of IGFs and IGFBPs in mammary gland during pregnancy and early postpartum in control and HT rats}

Compared with the other IGF system members, IGFBP-5 mRNA in situ hybridization resulted in very strong signals in the epithelial cells. This is in accordance with its higher abundance in relation to the other mRNAs. In spite of this, the non-radioactive in situ hybridization was meant to provide optimal localization, and the color reaction was stopped when discriminating signals with maximum intensities were reached. Its results cannot be compared with those obtained with the quantitative RT-PCR. IGFBP-5 mRNA was localized in the epithelial cells surrounding the lumina of the alveoli and also in the ducts (Fig. 6). There appeared to be no differences in distribution between control and HT rats (Fig. 6). Figure 6 shows in situ hybridization for IGF-I and IGFBP-2 which only gave signals in scattered epithelial and stromal cells and there was no difference in localization between control and HT rats. The distribution of the other IGFBPs was similar to IGFBP-2 (not shown).

\section{Discussion}

In the present study, we examined the effect of a daily $\mathrm{T}_{4}$ treatment on the IGF axis and on serum hormones in virgin, pregnant and postpartum rats. Daily administration of $\mathrm{T}_{4}$ provoked an increase in serum $\mathrm{T}_{3}$ that was, however, dependent on the stage of pregnancy or lactation. The decrease in $\mathrm{T}_{3}$ levels as pregnancy progressed may be caused by the increased plasma clearance rates for $\mathrm{T}_{3}$ and $\mathrm{T}_{4}$ caused by increased metabolization and excretion of free iodide from thyroid hormones in the liver and other peripheral tissues (3841). These modifications in thyroid hormone metabolism are completely reversed in the immediate postpartum period $(38,39)$ and may account for the marked rebound that we observed.

The hyperthyroid symptoms in these rats were similar to those previously described $(2,3)$ : increased food intake, advanced PRL secretion, unsuccesful lactation and premature delivery of an increased number of pups. Circulating $\mathrm{GH}$ was diminished in the virgin and postpartum HT rats, but was not modified in pregnant HT rats. This is in agreement with Giustina \& Wehrenberg (42) who demonstrated that elevated thyroid hormone levels inhibit GH secretion. In contrast, serum IGF-I concentrations were not modified by HT. This may indicate that $\mathrm{GH}$ is not the sole regulator of IGF secretion. As has already been described (16-18, 43), serum IGF-I declined during pregnancy and rebounded after delivery to virgin values. As previously described, the increase in body and liver weight in the HT virgin rats was abolished by the end of pregnancy (2). 

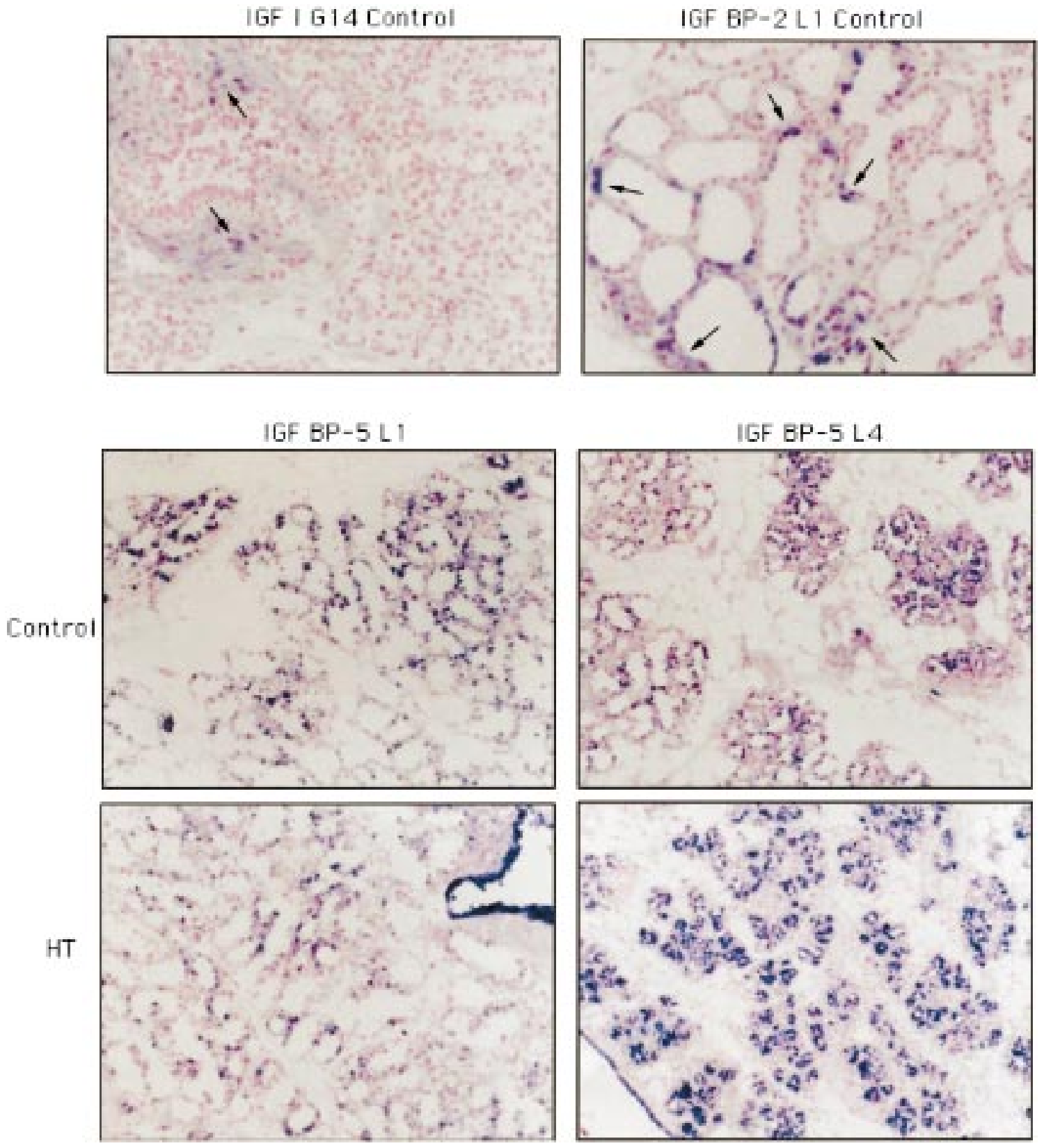

Figure 6 Representative in situ hybridizations for IGF-I, IGFBP-2 and IGFBP-5 in mammary tissue from pregnant and postpartum rats injected daily with $0.25 \mathrm{mg} / \mathrm{kg} \mathrm{T} \mathrm{T}_{4}(\mathrm{HT})$ or saline (controls; Co). Rats were killed at $1200 \mathrm{~h}$ on days 7 (G7), 14 (G14) and 21 (G21) of pregnancy or day 1 (L1) or 4 (L4) postpartum. L4 rats had been separated from their litters on L1. Arrows on the first two upper panels point to positive cells (blue).

The thyroid hormone regimen, as well as pregnancy per se also caused various modifications in the mRNA concentration of the components of the IGF system. There was an inverse relationship between IGF-I and IGF-II mRNA concentration in the mammary glands during pregnancy, with IGF-II mRNA high during the first half of pregnancy and increases in IGF-I mRNA in late pregnancy, which were delayed to postpartum in the HT rats. As has been shown for other tissues and experimental models, the mRNA concentration of IGFBP-3, and IGFBP-4 to a lesser extent, seem to be associated with that of IGF-I. This pattern of mRNA concentration may suggest that IGF-II participates in early mammogenesis, and is replaced by IGF-I in late pregnancy, during the stage of final differentiation of the mammary gland. The mRNA peak of IGF-I and maybe of IGFBP-3 and -4 in late pregnancy may be related to the sustained increase in GH (44) and in 
circulating estrogen (45) that occurs during late pregnancy, since both these hormones induce IGF-I expression in mammary tissue (46). Furthermore, the parallel increases in IGF-I and IGFBP-3 and -4 mRNAs, as well as IGF-II and IGFBP-2 may modulate the bioavailability of the IGFs in the tissues and, in the case of IGF-I, may increase the capability of the tissue to capture circulating IGF-I (47) and thus enhance its mitogenic properties. These temporal patterns may also suggest that IGF-I and IGF-II participate in the regulation of the local expression of the binding proteins. The increases observed in IGF-I around delivery may be related to a stimulation of mammary epithelial cell proliferation during this final stage of differentiation, and to the inhibition of mammary apoptosis (30).

Tonner et al. (30) demonstrated that PRL inhibits involution-related IGFBP- 5 expression in the mammary gland. Therefore, the lower levels of PRL on L1 may have been responsible for the increased mRNA levels of IGFBP-5 of the HT rats. The elevated IGFBP-5 mRNA levels may, in turn, participate in the initiation of involution caused by the absence of lactation in the HT group, through IGFBP-5-triggered apoptosis (6, 30 ). It has been demonstrated that the mammary involution and apoptosis induced by weaning depends on activation of Stat3, which in turn is necessary for the induction of IGFBP-5 (6). In the controls, the postpartum increase in IGFBP-5 was slower and the maximum observed on L4 may have been the consequence of weaning on L1, and thus initiation of involution. IGFBP-5 was localized mainly on the mammary epithelium and stroma, which are the structures most affected by the remodeling induced by the absence of lactation.

Both pregnancy and HT produce liver hypertrophy, and we have shown that in pregnant HT rats the effect is not additive, resulting in a liver growth that is not different from that produced by HT or pregnancy alone (2). HT in virgin rats did not alter liver IGF-I or IGFBP-3 and -4 mRNA concentrations, suggesting that the liver hypertrophy produced by this condition may not be mediated through changes in IGF or binding protein expression, or changes in circulating IGF-I. The changes in hepatic IGF-I mRNA during pregnancy and the postpartum were similar to those previously observed $(16,18)$. Hepatic IGF-I mRNA expression was not paralleled by serum concentrations of IGF-I. This is likely due to an increased plasmatic clearance of the hormone and a decrease in circulating IGFBP-3, causing a greater bioavailability of IGF to the tissues $(16,17,43)$. In contrast to the results of Donovan et al. (43), we found markedly decreased hepatic IGFBP-3 mRNA levels on G21, with a tendency to increase on L4. This parallels the reported variation in serum IGFBP-3 concentrations and the pattern of changes in circulating IGF-I, which regulates IGFBP3 synthesis positively (48). The decrease in liver
IGFBP-3 mRNA was offset by the increase in IGFBP-4 mRNA, which was also observed by Donovan et al. (43).

Although hypothyroidism lowers circulating and liver IGF-I concentrations, hyperthyroidism does not seem to modify serum or hepatic levels of this hormone in male or non-pregnant rats $(7,49,50)$. We also observed no significant modifications in liver mRNA concentration of IGF-I in virgin rats or during pregnancy, but the postpartum increase was advanced, perhaps reflecting the advancement in luteolysis and parturition (3). On the other hand, the effects of HT on liver IGFBP-3 and -4 mRNA were more marked and inverse, suggesting an opposite regulation of these proteins by thyroid hormones and pregnancy. The profound inhibitory effect of HT on IGFBP-3 liver mRNA concentration in the pregnant rats is in contrast with its effects on male rats, where thyrotoxicosis increases IGFBP-3 mRNA concentration (11). HT seemed to block any stimulatory effect by the circulating IGF-I on IGFBP-3 and this may be a particularity of pregnancy, again increasing the availability of IGF to these rats which carry an increased number of fetuses (3). On the other hand, IGFBP-4 mRNA concentration was increased by HT in male rats (51) as well as during pregnancy in this study, and may compensate for the decrease produced by HT in IGFBP-3, limiting the actions of IGF-I in this tissue. This may account, in part, for the similar liver hypertrophy observed in both groups of pregnant rats.

In conclusion, HT induced more pronounced effects on the IGF system in pregnant and postpartum rats than in virgin rats. In mammary glands, pregnancy per se produced marked effects on the gene expression patterns of IGF-I, IGF-II and IGFBPs. The changes observed may reflect specific temporal effects on mammary development and differentiation. Chronic hyperthyroidism did induce changes particularly related to temporal shifts in expression, with the exception of the pattern of IGFBP-5 mRNA concentration, which may be related to premature mammary involution. On the other hand, the patterns of variation of liver or mammary gland IGFs and IGFBPs between control and HT rats did not correlate with the changes in liver or mammary gland tissue hypertrophy previously observed $(2,3)$, indicating that the effects of HT on these parameters may not be mediated by changes in the expression of IGFs or their binding proteins.

\section{Acknowledgements}

This work was supported by grants (PMT-PICT 0441 and PMT-PICT 01930) from the Agencia de Promoción Científica y Tecnológica, Argentina and PLI-149/94 from PLACIRH. We thank Dr A F Parlow from the NHPP for the gifts of the PRL and GH RIA kits and Dr D Gardella de Rodriguez, Glaxo, Argentina, for the 
gift of $\mathrm{T}_{4} \cdot \mathrm{G} \mathrm{J}$ is a career scientist from CONICET. $\mathrm{R} \mathrm{R}$ was sponsored by the Human Capital and Mobility Programme of the EEC and D L-K and J vN were sponsored by the Sophia Foundation for Medical Research.

\section{References}

1 Becks GP \& Burrow GN. Thyroid disease and pregnancy. Medical Clinics of North America 199175 121-150.

2 Rosato RR, Jahn GA \& Gimenez MS. Amelioration of some metabolic effects produced by hyperthyroidism in late pregnant rats and their foetuses. Effects on lipids and proteins. Hormone and Metabolic Research 199224 15-20.

3 Rosato RR, Gimenez MS \& Jahn GA. Effects of chronic thyroid hormone administration on pregnancy, lactogenesis and lactation in the rat. Acta Endocrinologica 1992127 547-554.

4 Rosato RR, Jammes H \& Jahn GA. Effect of chronic thyroid hormone treatment on pregnancy in rats: effects on oestrogen, progesterone and prolactin receptors in uterus, liver and mammary gland. Endocrine Research 199824 269-284.

5 Humbel RE. Insulin-like growth factors I and II. European Journal of Biochemistry $1990190445-462$

6 Chapman RS, Lourenco PC, Tonner E, Flint DJ, Selbert S, Takeda $\mathrm{K}$ et al. Suppression of epithelial apoptosis and delayed mammary gland involution in mice with a conditional knockout of Stat3. Genes and Development 199913 20604-22616.

7 Harakawa S, Yamashita S, Tobinaga T, Matsuo K, Hirayu H, Izumi $\mathrm{M}$ et al. In vivo regulation of hepatic insulin-like growth factor-1 messenger ribonucleic acids with thyroid hormone. Endocrinologia Japonica 199037 205-211.

8 Ikeda T, Fujiyama K, Hoshino T, Tanaka Y, Takeuchi T, Mashiba H et al. Stimulating effect of thyroid hormone on insulin-like growth factor I release and synthesis by perfused rat liver. Growth Regulation 19911 39-41.

9 Nanto-Salonen K, Muller HL, Hoffman AR, Vu TH \& Rosenfeld RG. Mechanisms of thyroid hormone action on the insulin-like growth factor system: all thyroid hormone effects are not growth hormone mediated. Endocrinology 1993132 781-788.

10 Sugisaki T, Yamada T, Takamatsu K \& Noguchi T. The influence of endocrine factors on the serum concentrations of insulin-like growth factor-I (IGF-I) and IGF-binding proteins. Journal of Endocrinology 1993138 467-477.

11 Rodriguez-Arnao J, Miell J, Thomas M, McGregor AM \& Ross RJ. Changes in hepatic insulin-like growth factor-binding protein $-1,-2$ and -3 mRNA levels in rats with altered thyroid status. Journal of Endocrinology 1994140 251-255.

12 Muaku SM, Underwood LE, Selvais PL, Ketelslegers JM \& Maiter D. Maternal protein restriction early or late in rat pregnancy has differential effects on fetal growth, plasma insulin-like growth factor-I (IGF-I) and liver IGF-I gene expression. Growth Regulation $19955125-312$

13 Monaco MH \& Donovan SM. Moderate food restriction abolishes the pregnancy-associated rise in serum growth hormone and decreases serum insulin-like growth factor-I (IGF-I) concentrations without altering IGF-I mRNA concentration in rats. Journal of Nutrition $1996126544-553$.

14 Monaco MH \& Donovan SM. Moderate food restriction reduces serum IGF-I and alters circulating IGF-binding protein profiles in lactating rats. Journal of Endocrinology 1997152 303-316.

15 Higashi Y, Takenaka A. Takahashi S \& Noguchi T. Effect of protein restriction on messenger RNA of insulin-like growth factor-I and insulin-like growth factor-binding proteins in liver of ovariectomized rats. British Journal of Nutrition $199879447-453$.

16 Davenport ML, Clemmons DR, Miles MV, Camacho-Hubner C, D'Ercole AJ \& Underwood LE. Regulation of serum insulin-like growth factor-I (IGF-I) and IGF binding proteins during rat pregnancy. Endocrinology $19901271278-1286$.
17 Gargosky SE, Walton PE, Owens PC, Wallace JC \& Ballard FJ. Insulin-like growth factor-I (IGF-I) and IGF-binding proteins both decline in the rat during late pregnancy. Journal of Endocrinology $1990127383-390$.

18 Travers MT, Madon RJ \& Flint DJ. Regulation of serum insulin-like growth factor-I (IGF-I), hepatic growth hormone binding and IGF-I gene expression in the rat during pregnancy and lactation. Journal of Endocrinology 1993139 89-95.

19 Rosato R, Jammes H, Jahn GA, Belair L \& Djiane J. Growth hormone receptor and insulin-like growth factor-I: gene expression and regulation in rat mammary gland and liver. Endocrine 1994 2 1157-1162.

20 Murphy LJ \& Ghahary A. Uterine insulin-like growth factor-1: regulation of expression and its role in estrogen-induced uterine proliferation. Endocrine Reviews 199011 443-453.

21 Hadsell DL, Campbell PG \& Baumrucker CR. Characterization of the change in type I and II insulin-like growth factor receptors of bovine mammary tissue during the pre- and postpartum periods. Endocrinology 1990126 637-643.

22 Lavandero S, Santibanez JF, Ocaranza MP, Ferreira A \& SapagHagar M. Binding and production of insulin-like growth factor-I in rat mammary gland. Comparative Biochemistry and Physiology A 199199 507-511.

23 Marcotty C, Frankenne F, Meuris S \& Hennen G. Immunolocalization and expression of insulin-like growth factor I (IGF-I) in the mammary gland during rat gestation and lactation. Molecular and Cellular Endocrinology 199499 237-243.

24 Bussmann LE, Bussmann IM \& Charreau EH. Role of receptors for epidermal growth factor and insulin-like growth factors I and II in the differentiation of rat mammary glands from lactogenesis I to lactogenesis II. Journal of Reproduction and Fertility 1996107 $307-314$.

25 Richert MM \& Wood TL. The insulin-like growth factors (IGF) and IGF type I receptor during postnatal growth of the murine mammary gland: sites of messenger ribonucleic acid expression and potential functions. Endocrinology 1999140 454-461.

26 Weber MS, Boyle PL, Corl BA, Wong EA, Gwazdauskas FC \& Akers RM. Expression of ovine insulin-like growth factor-1 (IGF-1) stimulates alveolar bud development in mammary glands of transgenic mice. Endocrine 1998 8 251-259.

27 Weber MS, Purup S, Vestergaard M, Ellis SE, Scndergard-Andersen J, Akers RM et al. Contribution of insulin-like growth factor (IGF)-I and IGF-binding protein-3 to mitogenic activity in bovine mammary extracts and serum. Journal of Endocrinology 1999161 $365-373$.

28 LeRoith D, Neuenschwander S, Wood TL \& Henninghausen L. Insulin-like growth factor-I and insulin-like growth factor binding protein-3 inhibit involution of the mammary gland following lactation: studies in transgenic mice. Progress in Growth Factor Research 19956 433-436.

29 Neuenschwander S, Schwartz A, Wood TL, Roberts CT Jr, Henninghausen L \& LeRoith D. Involution of the lactating mammary gland is inhibited by the IGF system in a transgenic mouse model. Journal of Clinical Investigation 199697 2225-2232.

30 Tonner E, Barber MC, Travers MT, Logan A \& Flint DJ. Hormonal control of insulin-like growth factor-binding protein- 5 production in the involuting mammary gland of the rat. Endocrinology 1997 138 5101-5107.

31 Chomczynski P \& Sacchi N. Single-step method of RNA isolation by acid guanidinium thiocyanate-phenol-chloroform extraction. Analytical Biochemistry 1987162 156-159.

32 Puissant C \& Houdebine LM. An improvement of the single-step method of RNA isolation by acid guanidinium thiocyanatephenol-chloroform extraction. Biotechniques 19908 148-149.

33 Lindenbergh-Kortleve DJ, Rosato RR, van Neck JW, Nauta J, van Kleffens M, Groffen C et al. Gene expression of the insulin-like growth factor system during mouse kidney development. Molecular and Cellular Endocrinology 1997132 81-91.

34 Pane F, Salera A, Mostarda I, Salvatore F \& Sacchetti L. Estimation of extremely low amounts of single mRNAs by quantitative 
noncompetitive reverse transcription-polymerase chain reaction assay in biological specimens from normal and neoplastic cells. Analytical Biochemistry $1995 \mathbf{2 2 5} 362-366$.

35 Schuller AG, Zwarthoff EC \& Drop SL. Gene expression of the six insulin-like growth factor binding proteins in the mouse conceptus during mid- and late gestation. Endocrinology 1993132 2544-2550.

36 Schuller AGP, Groffen C, van Neck JW, Zwarthoff EC \& Drop SLS. cDNA cloning and mRNA concentration of the six mouse insulinlike growth factor binding proteins. Molecular and Cellular Endocrinology $1994 \mathbf{1 0 4} 57-66$.

37 Snedecor GW \& Cochran WG. Statistical Methods. Iowa: Iowa State University Press, 1967.

38 Galton VA. Thyroxine metabolism and thyroid function in the pregnant rat. Endocrinology $1968 \mathbf{8 2} 282-290$.

39 Fukuda H, Ohshima K, Mori M, Kobayashi I \& Greer MA. Sequential changes in the pituitary-thyroid axis during pregnancy and lactation in the rat. Endocrinology 1980107 1711-1716.

40 Calvo R, Obregon MJ, Ruiz de Ona C, Ferreiro B, Escobar Del Rey E \& Morreale de Escobar G. Thyroid hormone economy in pregnant rats near term: a physiological animal model of nonthyroidal illness? Endocrinology 1990127 10-16.

41 Versloot PM, Gerritsen J, Boogerd L, Schroder-van der Elst JP \& van Der Heide D. Thyroxine and 3,5,3'-triiodothyronine production, metabolism, and distribution in pregnant rat near term. American Journal of Physiology 1994267 E860-E867.

42 Giustina A \& Wehrenberg WB. Influence of thyroid hormones on the regulation of growth hormone secretion. European Journal of Endocrinology 1995133 646-653.

43 Donovan SM, Giudice LC, Murphy LJ, Hintz RL \& Rosenfeld RG. Maternal insulin-like growth factor-binding protein messenger ribonucleic acid during rat pregnancy. Endocrinology 1991129 3359-3366.

44 Jahn GA, Rastrilla AM \& Deis RP. Correlation of growth hormone secretion during pregnancy with circulating prolactin in rats. Journal of Reproduction and Fertility 199398 327-333.
45 Shaikh A. Estrone and estradiol levels in ovarian venous blood from rats during the estrous cycle and pregnancy. Biology of Reproduction $19715297-307$.

46 Ruan W, Catanese V, Wieczorek R, Feldman M \& Kleinberg DL. Estradiol enhances the stimulatory effect of insulin like growth factor-I (IGF-I) on mammary development and growth hormone induced IGF-I messenger ribonucleic acid. Endocrinology 1995 $1361296-1302$.

47 Van Neck JW, Flyvbjerg A, Schuller AG, Rosato RR, Groffen C, van Kleffens M et al. IGF, type I IGF receptor and IGF-binding protein mRNA concentration in kidney and liver of potassium-depleted and normal rats infused with IGF-I. Journal of Molecular Endocrinology $19971959-66$.

48 Jones JI \& Clemmons DR. Insulin-like growth factors and their binding proteins: biological actions. Endocrine Reviews 199516 3-34.

49 Thomas MR, Miell JP, Taylor AM, Ross RJ, Arnao JR, Jewitt DE et al. Endocrine and cardiac paracrine actions of insulin-like growth factor-I (IGF-I) during thyroid dysfunction in the rat: is IGF-I implicated in the mechanism of heart weight/body weight change during abnormal thyroid function? Journal of Molecular Endocrinology $199310313-323$.

50 Frystyk J, Gronbaek H, Skjaerbaek C \& Flyvbjerg A. Effect of hyperthyroidism on circulating levels of free and total IGF-I and IGFBPs in rats. American Journal of Physiology 1995269 E840-E845.

51 Demori I, Bottazzi C, Voci A, Gallo G, Scharf JG \& Fugassa E. Triiodothyronine increases insulin-like growth factor binding protein-4 expression in rat hepatocytes. Journal of Endocrinology $1997154155-165$.

Received 27 March 2001

Accepted 11 February 2002 